\title{
Correlation of CCR5 and NLRP3 gene polymorphisms with renal damage due to hepatitis $\mathbf{C}$ virus-related cryoglobulinemia
}

\author{
MENGJUN WANG ${ }^{1 *}$, QIULI LIU ${ }^{2 *}$ and CHUNHUA LIU ${ }^{2}$ \\ Departments of ${ }^{1}$ Urology and ${ }^{2}$ Infectious Disease, Liaocheng People's Hospital, \\ Liaocheng, Shandong 252000, P.R. China
}

Received December 13, 2017; Accepted July 18, 2018

DOI: 10.3892/etm.2018.6558

\begin{abstract}
Correlation of C-C chemokine receptor type 5 (CCR5) and NACHT, LRR and PYD domain-containing protein 3 (NLRP3) gene polymorphisms with renal damage due to hepatitis $\mathrm{C}$ virus (HCV)-related cryoglobulinemia were investigated. The 1:1 matched case-control study design was adopted, 171 patients with renal damage due to HCV-related cryoglobulinemia were selected as the case group, and 171 patients without renal damage were selected as the control group. Polymerase chain reaction and restriction fragment length polymorphism (PCR-RFLP) analysis was used to detect the polymorphisms of locus rs1799987A/G in CCR5 gene and locus rs35829419A/C in NLRP3 gene of 171 pairs of HCV patients. SPSS 20.0 software was used for logistic regression analysis, and genetics package of the $\mathrm{R}$ programming language for Hardy-Weinberg equilibrium test. The frequencies of locus rs1799987A/G in CCR5 gene in the case group were 48.0 and $52.0 \%$, while those in the control group were 47.9 and $52.1 \%$; the frequencies of locus rs35829419A/C in NLRP3 gene were 55.8 and $44.2 \%$, while those in the control group were 55.3 and $44.7 \%$. The results of logistic regression analysis showed that the distribution of CCR5 gene polymorphism in the case group was statistically different from that in the control group $(\mathrm{P}<0.05)$, which had a statistical correlation with the renal damage due to HCV-related cryoglobulinemia $(\mathrm{P}<0.05)$. At rs1799987, GG genotype was compared with AA genotype, and AG genotype was compared with AA genotype; the results showed that the renal damage due to $\mathrm{HCV}$-related cryoglobulinemia was not decreased [odds ratio $(\mathrm{OR})=0.91,95 \%$ confidence interval (95\% CI): 0.47-1.54; OR $=0.89,95 \%$ CI: 0.49-1.31]
\end{abstract}

Correspondence to: Dr Chunhua Liu, Department of Infectious Disease, Liaocheng People's Hospital, 67 Dongchang West Road, Dongchangfu, Liaocheng, Shandong 252000, P.R. China

E-mail: hcz2ed@163.com

*Contributed equally

Key words: gene polymorphism, damage due to cryoglobulinemia, hepatitis C virus, CCR5, NLRP3
The negative analysis model of the GG genotype reduced the risk of renal damage due to HCV-related cryoglobulinemia remarkably (OR $=0.62,95 \%$ CI: 0.39-0.98). Rs $1799987 \mathrm{~A} / \mathrm{G}$ and gene polymorphism of CCR5 may be associated with renal damage due to HCV-related cryoglobulinemia, and the carriage of $\mathrm{G}$ allele may lower the incidence rate of the disease, while rs35829419A/C in NLRP3 has no correlation with renal damage due to $\mathrm{HCV}$-related cryoglobulinemia.

\section{Introduction}

Cryoglobulinemia is one of the most common extrahepatic manifestations of hepatitis $\mathrm{C}$ virus (HCV) infection, whose main mode is to activate diffuse vasculitis in complement by means of precipitation of immune complexes in blood vessels and tissues, while a large amount of precipitates is usually accumulated into the skin and kidney (1-3). Renal damage, as one of the fairly critical diseases clinically, is a public health and safety problem around the world at present. More than $50 \%$ of patients with renal damage need to be treated with renal transplantation (4). It has also been reported that $\mathrm{HCV}$ infection is associated with renal damage due to cryoglobulinemia (5).

As an important chemokine receptor, $\mathrm{C}-\mathrm{C}$ chemokine receptor type 5 (CCR5) plays a vital role in the regulation of $\mathrm{T}$ cells as well as the migration, proliferation and immune function of monocytes. In particular, it plays a key role in summoning and activating immune cells at the inflammation site (6). As for NACHT, LRR and PYD domain-containing protein 3 (NLRP3), a subfamily of NLR family, increasing number of studies have proven that it participates in and causes inflammatory diseases (7). In the study of Rosengren et al (8), it was indicated that cholesterol can act as an activator of NLRP3, and it can lead to the occurrence of rheumatoid arthritis. However, there has been no report on the gene polymorphisms of CCR5 and NLRP3 in renal damage due to HCV-related cryoglobulinemia yet; therefore, the CCR5 and NLRP3 genotyping analyses were conducted for 171 patients with renal damage due to HCV-related cryoglobulinemia via polymerase chain reaction and restriction fragment length polymorphism (PCR-RFLP) in this investigation, so as to explore the correlation of loci rs1799987 and rs35829419 in the genes with renal damage due to HCV-related cryoglobulinemia. 


\section{Patients and methods}

Patients data. A total of $458 \mathrm{HCV}$ patients who were diagnosed in Liaocheng hospital from January 2015 to December 2016 according to the diagnostic criteria of the 'Guidelines for Prevention and Treatment of Hepatitis C' (9) in 2015 were included. Cryoglobulin precipitation occurs at $4^{\circ} \mathrm{C}$, and disappear at $37^{\circ} \mathrm{C}$, and the persistence of precipitation at $4^{\circ} \mathrm{C}$ is the standard. Combined with decreased serum cryosporin complement C4 and cryoglobulin content $>1 \mathrm{mg} / \mathrm{ml}, 264$ patients with HBV-related cryoglobulinemia were identified, accounting for $57.64 \%$ of patients with HCV. Finally, 171 cases with renal damage of HCV-related cryoglobulinemia were screened out by X-ray examination (the enlargement of renal shadow implies subcapsular hematoma, while the enlargement of renal shadow implies perirenal hemorrhage) and routine urinalysis (urine protein 2.0-4.0 g/l and urine occult blood positive), accounting for $37.33 \%$ of all $\mathrm{HCV}$ patients and $64.77 \%$ of patients with HCV-related cryoglobulinemia. In addition, 171 patients without renal damage were selected, which consisted of 80 men and 91 women, with an average age of $47.4 \pm 6.3$ years, and there were no statistically significant differences in the age and sex between the two groups of patients $(\mathrm{P}>0.05)$. The study was approved by the Ethics Committee of Liaocheng People's Hospital (Liaocheng, China). All the patients and their families were informed on the research and signed the informed consent, and the patients were treated and followed up. The clinical data of the patients are shown in Table I.

Inclusion criteria: patients who had no blood relation with one another; patients without a history of administration of nephrotoxic drugs; patients without liver cirrhosis and autoimmune disease; patients without malignant tumor, depression, hypertension or diabetes.

Exclusion criteria: patients with a course of disease shorter than half a year; pregnant and breast-feeding women; patients receiving drug therapies; patients with other genetic diseases; patients not undergoing radiotherapy and chemotherapy; patients with autism, memory impairment or hearing impairment; patients not co-operating with follow-up.

\section{Methods}

Deoxyribonucleic acid (DNA) extraction. An anticoagulant tube containing ethylenediamine tetraacetic acid-potassium (EDTA-K) was used to draw $5 \mathrm{ml}$ peripheral venous blood from the patients. The sample was then stored in a refrigerator at $-80^{\circ} \mathrm{C}$ for standby application, and extraction was performed according to the kit instructions. The DNA concentration with a ratio of optical density (OD) 260/OD280 at 1.8-2.0 was measured via an ultraviolet spectrophotometer (Hitachi, Tokyo, Japan). The DNA purity was detected using fluorescence electrophoresis.

Polymorphism detection. The reaction system was established in accordance with the instructions of TaqMan ${ }^{\mathrm{TM}}$ Universal PCR Master Mix kit: 5.0 $\mu \mathrm{l}$ 2X TaqMan Master Mix, $0.5 \mu \mathrm{l}$ forward primer $(15 \mu \mathrm{mol} / \mathrm{l}), 0.5 \mu \mathrm{l}$ reverse primer (15 $\mu \mathrm{mol} / \mathrm{l}), 15.0 \mu \mathrm{l}$ probe $(15 \mu \mathrm{mol} / \mathrm{l}), 25.0 \mu \mathrm{l}$ probe $(15 \mu \mathrm{mol} / \mathrm{l})$ and $3.0 \mu 1$ DNA template $(15 \mathrm{mg} / \mathrm{l})$. The concentration of sample DNA was $15 \mathrm{mg} / \mathrm{l}$. Reaction conditions: pre-denaturation at $95^{\circ} \mathrm{C}$ for $10 \mathrm{~min}$, denaturation at $95^{\circ} \mathrm{C}$ for $20 \mathrm{sec}$, annealing at $60^{\circ} \mathrm{C}$ for $40 \mathrm{sec}$ and extension at $72^{\circ} \mathrm{C}$ for $1 \mathrm{~min}$ were regarded
Table I. Clinical data sheet of the patients (n, \%).

\begin{tabular}{|c|c|c|c|c|}
\hline & $\begin{array}{l}\text { Patients } \\
\text { group } \\
(n=171)\end{array}$ & $\begin{array}{l}\text { Control } \\
\text { group } \\
(\mathrm{n}=171)\end{array}$ & $\chi^{2}$ & P-value \\
\hline Sex & & & 0.684 & 0.674 \\
\hline Male & $104(39.18)$ & $80(46.78)$ & & \\
\hline Female & $67(60.82)$ & $91(53.22)$ & & \\
\hline Age & & & 0.811 & 0.765 \\
\hline$<50$ years & $87(50.88)$ & $81(47.36)$ & & \\
\hline$\geq 50$ years & $84(49.12)$ & $90(52.64)$ & & \\
\hline Smoking history & & & 1.538 & 0.115 \\
\hline Yes & $59(34.50)$ & $61(35.67)$ & & \\
\hline No & $112(65.50)$ & $110(64.33)$ & & \\
\hline Exercise habit & & & 1.047 & 0.174 \\
\hline Yes & $37(21.64)$ & $93(54.38)$ & & \\
\hline No & $134(78.36)$ & $78(45.62)$ & & \\
\hline Place of residence & & & 1.79 & 0.188 \\
\hline City & $152(88.89)$ & $149(87.13)$ & & \\
\hline Countryside & $19(11.11)$ & $22(12.86)$ & & \\
\hline Nation & & & 2.646 & 0.082 \\
\hline Han & $117(68.42)$ & $134(78.36)$ & & \\
\hline Minority & $54(31.58)$ & $37(21.64)$ & & \\
\hline Educational level & & & 1.407 & 0.172 \\
\hline $\begin{array}{l}<\text { Senior high } \\
\text { school }\end{array}$ & $91(53.22)$ & $119(69.59)$ & & \\
\hline $\begin{array}{l}\geq \text { Senior high } \\
\text { school }\end{array}$ & $80(46.78)$ & $52(30.41)$ & & \\
\hline Marital status & & & 2.476 & 0.349 \\
\hline Married & $158(92.40)$ & $149(87.13)$ & & \\
\hline Single & $7(4.09)$ & $10(5.84)$ & & \\
\hline Widowed & $6(3.51)$ & $12(7.03)$ & & \\
\hline $\begin{array}{l}\text { Dietary } \\
\text { preference }\end{array}$ & & & 1.848 & 0.124 \\
\hline Light & $88(51.46)$ & $69(21.63)$ & & \\
\hline Spicy & $83(48.54)$ & $134(78.36)$ & & \\
\hline Alcoholism & & & 2.478 & 0.244 \\
\hline Yes & $64(37.43)$ & $43(25.14)$ & & \\
\hline No & $107(62.57)$ & $128(74.85)$ & & \\
\hline
\end{tabular}

as a cycle, and 40 cycles were conducted; at the end of the cycles, an extension was performed at $72^{\circ} \mathrm{C}$ for $7 \mathrm{~min}$. The PCR products were stored at $4^{\circ} \mathrm{C}$. Enzyme digestion of PCR products: a total of $20 \mu \mathrm{l}$ enzyme digestion system was stored at $36^{\circ} \mathrm{C}$ for 18-24 h, 3\% agarose gel electrophoresis was conducted for the products of enzyme digestion, and the gel imaging system was used for analysis. The primer sequences are shown in Table II.

Instruments and reagents. TaqMan ${ }^{\mathrm{TM}}$ Universal PCR Master Mix kit and GENESYS 10S ultraviolet spectrophoto meter (Thermo Fisher Scientific, Inc., Waltham, MA, USA); PCR instrument and DNA amplification kit (Applied Biosystems; Thermo Fisher Scientific, Inc.); U6 internal reference primer (Beyotime, Shanghai, China); gel imaging analysis system (Beijing Maisiqi High-tech Co., Ltd., Beijing, China). 
Table II. The primer sequences.

Forward sequence

Reverse sequence

\begin{tabular}{lll}
\hline U6 internal reference & 5'-CTCGCTTCGGCAGCACA-3' & 5'-AACGCTTCACGAATTTGCGT-3' \\
Rs1799987 & 5-GAAGGTGACCAAGTTCATGCT & 5-GAAGGTCGGAGTCAACGGATT \\
Rs35829419 & GGACTTCACATTAACCCTGTGT-3' & GGACTTCACATTAACCCTGTGC-3' \\
\hline
\end{tabular}

Statistical analysis. Hardy-Weinberg equilibrium test was performed for the obtained data using the genetics package of the $\mathrm{R}$ programming language, and $\mathrm{P} \geq 0.05$ indicated that the genetic frequency conformed to the Hardy-Weinberg law; Statistical Product and Service Solutions (SPSS) 20.0 (Beijing Sichuang Weida Information Technology Co., Ltd., Beijing, China) was used for statistical analysis. The patient data and other clinical data were presented as mean \pm standard deviation. t-test was utilized for intergroup comparisons of measurement data between the groups, and $\chi^{2}$ test was adopted for intergroup comparisons of enumeration data. Logistic regression analysis was used. $\mathrm{P}<0.05$ was considered to indicate a statistically significant difference.

\section{Results}

Hardy-Weinberg equilibrium analysis. The genotypic frequencies of single nucleotide polymorphism (SNP) (rs1799987 and rs35829419) loci of 2 genes were counted through the genetics package analysis; it was found that the gene frequencies of rs1799987 and rs35829419 in both the control and case groups conformed to the Hardy-Weinberg law $(\mathrm{P}>0.05)$, indicating that this research is representative (Table III).

Genotype analysis. In this research, the frequencies of the selected AA, GG and AG genotypes as well as A and G alleles at locus rs1799987 in the promoter region of CCR5 gene at SNPs loci in the case group were 21 (12.3\%), 29 (17.0\%) and $121(70.7 \%)$ as well as $163(48.0 \%)$ and $179(52.0 \%)$, respectively; those in the control group were 23 (16\%), $30(33 \%)$ and $118(51 \%)$ as well as $164(47.9 \%)$ and $178(52.1 \%)$, respectively. There were statistically significant differences in the genotype distribution between the two groups $(\mathrm{P}<0.05)$. As for the gene locus rs35829419 in the promoter region of NLRP3 gene, the frequencies of AA, CC and $\mathrm{AC}$ genotypes as well as $\mathrm{A}$ and $\mathrm{C}$ alleles in the case group were $41(23.9 \%), 21(12.3 \%)$ and $109(63.8 \%)$ as well as $191(55.8 \%)$ and $151(44.2 \%)$, respectively, and those in the control group were $37(21.6 \%), 19(11.1 \%)$ and $115(67.3 \%)$ as well as $189(55.3 \%)$ and $153(44.7 \%)$, respectively. The differences between the two groups were not statistically significant ( $\mathrm{P}>0.05$ ) (Table IV).

Susceptibility analysis. According to the genotype analysis, the association between selected SNP loci and susceptibility to renal damage due to HCV-related cryoglobulinemia was analyzed. At locus rs1799987 in the promoter region of CCR5 gene, the GG genotype was compared with AA genotype, and AG genotype was compared with AA genotype. The results indicated that the renal damage due to HCV-related cryoglobulinemia was not decreased [odds ratio $(\mathrm{OR})=0.91,95 \%$ confidence interval
Table III. Hardy-Weinberg equilibrium analysis.

\begin{tabular}{lccccc}
\hline & \multicolumn{2}{c}{ Patients group } & & \multicolumn{2}{c}{ Control group } \\
\cline { 2 - 3 } \cline { 6 - 7 } Gene locus & $\chi^{2}$ & P-value & & $\chi^{2}$ & P-value \\
\hline rs1799987 & 0.847 & 0.394 & & 0.415 & 0.547 \\
rs35829419 & 2.684 & 0.094 & & 0.294 & 0.671 \\
\hline
\end{tabular}

Table IV. Distribution of alleles and genotypes at gene loci in the case and control groups.

\begin{tabular}{lcccc}
\hline SNP & $\begin{array}{c}\text { Case } \\
\text { group }\end{array}$ & $\begin{array}{c}\text { Control } \\
\text { group }\end{array}$ & $\chi^{2}$ & P-value \\
\hline rs1799987 & & & & \\
Genotype & & & 5.845 & 0.039 \\
AA & $21(12.3 \%)$ & $23(16 \%)$ & & \\
GG & $29(17.0 \%)$ & $30(33 \%)$ & & \\
AC & $121(70.7 \%)$ & $118(51 \%)$ & & \\
Allele & & & 4.374 & 0.043 \\
A & $163(47.66 \%)$ & $164(47.9 \%)$ & & \\
G & $179(52.34 \%)$ & $178(52.1 \%)$ & & \\
rs35829419 & & & & \\
Genotype & & & 1.674 & 0.484 \\
AA & $41(23.9 \%)$ & $37(21.6 \%)$ & & \\
CC & $21(12.3 \%)$ & $19(11.1 \%)$ & & \\
AC & $109(63.8 \%)$ & $115(67.3 \%)$ & & \\
Allele & & & 0.978 & 0.413 \\
A & $191(55.8 \%)$ & $189(55.3 \%)$ & & \\
C & $151(44.2)$ & $153(44.7 \%)$ & & \\
\hline
\end{tabular}

SNP, single nucleotide polymorphism.

(95\% CI): 0.47-1.54; OR = 0.89, 95\% CI: 0.49-1.31]. However, it was discovered from negative analysis model that the GG genotype reduced the risk of renal damage due to $\mathrm{HCV}$-related cryoglobulinemia remarkably $(\mathrm{OR}=0.62,95 \% \mathrm{CI}$ : 0.39-0.98). It was found in allele model that the carriage of $\mathrm{G}$ allele could effectively lower the risk of renal damage due to HCV-related cryoglobulinemia (OR $=0.88,95 \%$ CI: 0.67-1.02), while locus rs35829419 was not related to the susceptibility to renal damage due to HCV-related cryoglobulinemia (Table V).

Correlation analysis. Logistic regression analysis was conducted with the clinical data, locus rs1799987 A/G and 
Table V. Association between selected SNP loci and susceptibility to renal damage due to HCV-related cryoglobulinemia.

\begin{tabular}{|c|c|c|c|c|c|c|}
\hline SNP & Model & Gene & Patients group & Control group & OR & P-value \\
\hline \multirow[t]{4}{*}{ es1799987 } & Positive model & $\mathrm{AG}+\mathrm{GG}$ & $142(83.0 \%)$ & $141(82.4 \%)$ & $0.91(0.47-1.54)$ & 0.574 \\
\hline & Negative model & $\begin{array}{l}\mathrm{AG}+\mathrm{AA} \\
\mathrm{GG}\end{array}$ & $\begin{array}{r}50(29.2 \%) \\
121(70.8 \%)\end{array}$ & $\begin{array}{r}53(31.0 \%) \\
118(69.0 \%)\end{array}$ & $\begin{array}{l}0.89(0.49-1.31) \\
0.62(0.39-0.98)\end{array}$ & $\begin{array}{l}0.431 \\
0.010\end{array}$ \\
\hline & Common model & $\begin{array}{l}\text { AA } \\
\text { AG } \\
\text { GG }\end{array}$ & $\begin{array}{r}21(12.3 \%) \\
29(17.0 \%) \\
121(70.7 \%)\end{array}$ & $\begin{array}{r}23(16 \%) \\
30(33 \%) \\
118(51 \%)\end{array}$ & $\begin{array}{c}1 \\
0.94(0.59-1.47) \\
0.74(0.39-1.24)\end{array}$ & $\begin{array}{l}0.864 \\
0.068\end{array}$ \\
\hline & Allele model & $\mathrm{G} / \mathrm{A}$ & & & $0.88(0.67-1.02)$ & 0.032 \\
\hline \multirow{4}{*}{ rs35829419 } & Positive model & $\mathrm{AG}+\mathrm{GG}$ & $150(88.7 \%)$ & $142(83.0 \%)$ & $1.14(0.88-1.54)$ & 0.234 \\
\hline & Negative model & $\begin{array}{l}\mathrm{AG}+\mathrm{AA} \\
\mathrm{GG}\end{array}$ & $\begin{array}{l}130(76.0 \%) \\
109(63.8 \%)\end{array}$ & $\begin{array}{r}56(32.7 \%) \\
115(67.3 \%)\end{array}$ & $\begin{array}{c}1.02(0.63-1.57) \\
1\end{array}$ & 0.841 \\
\hline & Common model & $\begin{array}{l}\text { AA } \\
\text { AG } \\
\text { GG }\end{array}$ & $\begin{array}{r}41(23.9 \%) \\
21(12.3 \%) \\
109(63.8 \%)\end{array}$ & $\begin{array}{r}37(21.6 \%) \\
19(11.1 \%) \\
115(67.3 \%)\end{array}$ & $\begin{array}{c}1 \\
1.09(0.81-1.39) \\
1.1(0.68-1.76)\end{array}$ & $\begin{array}{l}0.274 \\
0.641\end{array}$ \\
\hline & Allele model & $\mathrm{G} / \mathrm{A}$ & & & $1(0.81-1.34)$ & 0.97 \\
\hline
\end{tabular}

SNP, single nucleotide polymorphism; HCV, hepatitis C virus; OR, odds ratio.

Table VI. Logistic regression.

\begin{tabular}{lcccc}
\hline Gene locus & $\beta$ & Wald $\chi^{2}$ & P-value & OR (95\% CI) \\
\hline Rs1799987 & -0.263 & 5.941 & 0.0041 & $0.597(0.427-0.954)$ \\
Rs35829419 & 0.084 & 0.061 & 0.834 & $1.041(0.684-0.167)$
\end{tabular}

OR, odds ratio; CI, confidence interval.

locus rs35829419 A/C as independent variables and whether the patients had renal damage due to HCV-related cryoglobulinemia as the dependent variable. It was found through result analysis that locus rs $1799987 \mathrm{~A} / \mathrm{G}$ notably increased the onset risk of renal damage due to $\mathrm{HCV}$-related cryoglobulinemia $(\mathrm{OR}=3.417,95 \% \mathrm{CI}=1.574-4.748 ; \mathrm{P}<0.01)$; locus rs35829419 $\mathrm{A} / \mathrm{C}(\mathrm{OR}=3.417,95 \% \mathrm{CI}=0.338-1.459 ; \mathrm{P}>0.05)$ and other clinical data did not enter the logistic regression equation, suggesting that they were not obviously associated with renal damage due to HCV-related cryoglobulinemia (Table VI).

\section{Discussion}

Mixed cryoglobulin is generated in the body of $>50 \% \mathrm{HCV}$ patients, and nearly two thirds of the patients are vulnerable to cryoglobulinemia, especially type II cryoglobulinemia with monoclonal immunoglobulin $\mathrm{M}(\operatorname{IgM})$ rheumatoid factor (RF), which is closely related to patients with $\mathrm{HCV}$ infection and is extremely easy to cause renal damage (10-12). As one of the active RFs, $\operatorname{IgM} \kappa(\operatorname{IgM} \kappa)$ can form complexes with very low-density lipoproteins of $\mathrm{HCV}$ and apolipoprotein E2 (ApoE2), which is an important reason for inducing $\mathrm{HCV}(1,13) . \operatorname{IgM\kappa }$ is an $\mathrm{IgG}$ antibody, which can combine with anti-HCV IgG to form immune complex precipitation, glomerular subendothelial space and glomerular mesangium. Finally, renal damage is triggered by activation of partial complements, formation of chemokines and other factors $(14,15)$.
In this study, the patients with renal damage due to HCV-related cryoglobulinemia were detected via PCR-RFLP to explore the correlation of CCR5 and NLRP3 gene polymorphisms in the disease. The results revealed that there were statistical differences in the genotype distributions at gene locus CCR5-rs1799987 between the patients with renal damage due to HCV-related cryoglobulinemia and the control group $(\mathrm{P}<0.05)$. It is suggested that the gene distribution at locus rs1799987 is associated with renal damage due to HCV-related cryoglobulinemia. In addition, this locus has a close correlation with pulmonary infection. A previous study (16) reported that locus rs1799987 is a risk genotype that is related to the susceptibility of Chinese Han people to tuberculosis. However, it was mentioned in the paper of Carpenter et al (17) that locus rs1799987 is not related to the susceptibility to tuberculosis in adults in Peru, indicating that the locus has regional and racial differences. In the present study, it was found that gene locus NLRP3-rs35829419 had no relations with renal damage due to HCV-related cryoglobulinemia, so a gene locus was excluded effectively, providing a clear direction for future studies in a better way. At the same time, the correlation research on the CCR5 and NLRP3 gene polymorphisms and susceptibility to renal damage due to HCV-related cryoglobulinemia were conducted by virtue of case-control study for the first time, and the results showed that there were statistical differences in the genotype and allele distributions of locus CCR5-rs1799987 as well as susceptibility to renal damage due to HCV-related cryoglobulinemia, of which $\mathrm{G}$ allele could effectively lower the risk of the disease $(\mathrm{OR}=0.62,95 \% \mathrm{CI}$ : $0.39-0.98 ; \mathrm{P}=0.010)$. It is indicated that the incidence rate of renal damage due to $\mathrm{HCV}$-related cryoglobulinemia can be effectively reduced in people carrying $\mathrm{G}$ allele.

The understanding of CCR5 starts from inflammations. Under physiological and pathological conditions, it plays a crucial role in communication with and movement in leukocytes (18). Currently, studies on CCR5 gene polymorphism have discovered its role in many diseases, and its role is especially significant in human immune system defect. It was mentioned 
in the paper of Aguilar et al (19) that CCR5 gene polymorphism plays a part in the generation of anti-double-stranded DNA (dsDNA) autoantibody and the occurrence of lupus nephritis. Furthermore, the report of Tebas et al (20) mentioned that CCR5 exerts vital regulating effects in the process of human immunodeficiency virus type 1 (HIV-1) infection.

There were still some limitations in this study; there were plenty of SNPs in CCR5 and NLRP3, and further studies on the relationship between different loci and the onset risk of renal damage due to HCV-related cryoglobulinemia are needed. Moreover, the susceptibility-related study was conducted only for CCR5 and NLRP3 gene polymorphisms in this study, and the sample size was small, so it could not prove this experiment was representative; therefore, studies with larger sample sizes are needed in the future to reduce bias of the experimental results.

In conclusion, CRR5-rs1799987 gene polymorphism is associated with renal damage due to HCV-related cryoglobulinemia, and the $\mathrm{G}$ allele can effectively lower the onset risk of the disease, while NLRP3-rs35829419 has no correlation with renal damage due to $\mathrm{HCV}$-related cryoglobulinemia.

\section{Acknowledgements}

Not applicable.

\section{Funding}

No funding was received.

\section{Availability of data and materials}

The datasets used and/or analyzed during the present study are available from the corresponding author on reasonable request.

\section{Authors' contributions}

MW conceived, designed and drafted the study. QL and CL collected, analyzed and interpreted the patient data, and revised the manuscript critically for important intellectual content. All authors have read and approved the final manuscript.

\section{Ethics approval and consent to participate}

The study was approved by the Ethics Committee of Liaocheng People's Hospital (Liaocheng, China). Signed informed consents were obtained from the patients or guardians.

\section{Patient consent for publication}

Not applicable.

\section{Competing interests}

The authors declare that they have no competing interests.

\section{References}

1. Cacoub P, Comarmond C, Domont F, Savey L and Saadoun D: Cryoglobulinemia Vasculitis. Am J Med 128: 950-955, 2015.
2. Gragnani L, Fognani E, Piluso A, Boldrini B, Urraro T, Fabbrizzi A, Stasi C, Ranieri J, Monti M, Arena U, et al; MaSVE Study Group: Long-term effect of HCV eradication in patients with mixed cryoglobulinemia: A prospective, controlled, open-label, cohort study. Hepatology 61: 1145-1153, 2015.

3. Alpers CE and Smith KD: Cryoglobulinemia and renal disease. Curr Opin Nephrol Hypertens 17: 243-249, 2008.

4. Mishra J, Dent C, Tarabishi R, Mitsnefes MM, Ma Q, Kelly C, Ruff SM, Zahedi K, Shao M, Bean J, et al: Neutrophil gelatinase-associated lipocalin (NGAL) as a biomarker for acute renal injury after cardiac surgery. Lancet 365: 1231-1238, 2005.

5. Weimer LE, Vinci M, Borgia G, Brunetto M, Sturace L, Gaeta GB, Chemello L, Buggio A, Andreone P and Raimondo G: HCV-related mixed cryoglobulinemia: Data from PITER, a nationwide Italian HCV cohort study. Digestive and Liver Disease 48: e6-e7, 2016.

6. Eltayeb S, Berg AL, Lassmann H, Wallström E, Nilsson M, Olsson T, Ericsson-Dahlstrand A and Sunnemark D: Temporal expression and cellular origin of CC chemokine receptors CCR1, CCR 2 and CCR 5 in the central nervous system: insight into mechanisms of MOG-induced EAE. J Neuroinflammation 4: 1-13, 2007.

7. Stutz A, Kolbe CC, Stahl R, Horvath GL, Franklin BS, van Ray O, Brinkschulte R, Geyer M, Meissner F and Latz E: NLRP3 inflammasome assembly is regulated by phosphorylation of the pyrin domain. J Exp Med 214: 1725-1736, 2017.

8. Rosengren S, Hoffman HM, Bugbee W and Boyle DL: Expression and regulation of cryopyrin and related proteins in rheumatoid arthritis synovium. Ann Rheum Dis 64: 708-714, 2005.

9. Dong JI, You SL and Xin SJ: Interpretation of the Chinese guideline of prevention and treatment for hepatitis C (2015 updated version). Infectious Disease Information 1: 20-23, 2016.

10. Saadoun D, Pol S, Ferfar Y, Alric L, Hezode C, Si Ahmed SN, de Saint Martin L, Comarmond C, Bouyer AS, Musset L, et al: Efficacy and safety of sofosbuvir plus daclatasvir for treatment of HCV-associated cryoglobulinemia vasculitis. Gastroenterology 153: 49-52.e5, 2017.

11. Palombo SB, Wendel EC, Kidd LR, Yazdi F and Naljayan MV; Clinical Nephrology: MPGN and mixed cryoglobulinemia in a patient with hepatitis $\mathrm{C}$ - new treatment implications and renal outcomes. Clin Nephrol Case Stud 5: 66-69, 2017.

12. Tang L, Marcell L and Kottilil S: Systemic manifestations of hepatitis C infection. Infect Agent Cancer 11: 29, 2016.

13. Okazaki M, Yaomura T, Tsuboi T, Mizuno S, Nakamura T, Hasegawa T, Katayama M, Nakamura H, Iida H, Saito T, et al: A case of acute renal failure of multiple myeloma due to monoclonal type I cryoglobulinemia with thrombotic microangiopathy. CEN Case Rep 4: 174-179, 2015.

14. Quartuccio L, Zuliani F, Corazza L, Scaini P, Zani R, Lenzi M, Tavoni A, Sebastiani M, Baldovino S, Urraro T, et al: Retreatment regimen of rituximab monotherapy given at the relapse of severe HCV-related cryoglobulinemic vasculitis: Long-term follow up data of a randomized controlled multicentre study. J Autoimmun 63: 88-93, 2015.

15. Basile U, Gulli F, Gragnani L, Fognani E, Napodano C, Pocino K, Zignego AL and Rapaccini GL: IgG3 subclass: A possible trigger of mixed cryoglobulin cascade in hepatitis $\mathrm{C}$ virus chronic infection. Dig Liver Dis 49: 1233-1239, 2017.

16. Murooka TT, Wong MM, Rahbar R, Majchrzak-Kita B, Proudfoot AE and Fish EN: CCL5-CCR5-mediated apoptosis in T cells: Requirement for glycosaminoglycan binding and CCL5 aggregation. J Biol Chem 281: 25184-25194, 2006.

17. Carpenter D, Taype C, Goulding J, Levin M, Eley B, Anderson S, Shaw MA and Armour JA: CCL3L1 copy number, CCR5 genotype and susceptibility to tuberculosis. BMC Med Genet 15: 5, 2014.

18. Dobaczewski M, Xia Y, Bujak M, Gonzalez-Quesada C and Frangogiannis NG: CCR5 signaling suppresses inflammation and reduces adverse remodeling of the infarcted heart, mediating recruitment of regulatory T cells. Am J Pathol 176: 2177-2187, 2010.

19. Aguilar F, Núñez-Roldán A, Torres B, Wichmann I, Sánchez-Román J and González-Escribano MF: Chemokine receptor CCR2/CCR5 polymorphism in Spanish patients with systemic lupus erythematosus. J Rheumatol 30: 1770-1774, 2003.

20. Tebas P, Stein D, Tang WW, Frank I, Wang SQ, Lee G, Spratt SK, Surosky RT, Giedlin MA, Nichol G, et al: Gene editing of CCR5 in autologous CD4 T cells of persons infected with HIV. N Engl J Med 370: 901-910, 2014. 